Bangladesh J. Sci. Res. 27(1): 39-50, 2015 (June)

\title{
VOLTAMMETRIC STUDY OF THE INTERACTIONS OF ALKALINE EARTH METAL IONS AND MELAMINE AT DIFFERENT pH
}

\author{
Farhana Haque, Afroza Khatun, P.K. Bakshi and A.A. Shaikh* \\ Department of Chemistry, University of Dhaka, Dhaka 1000, Bangladesh
}

\begin{abstract}
The electrochemical redox behavior of alkaline earth metal ions at different $\mathrm{pH}$ in acetate buffer solution has been investigated using cyclic voltammetric method at gold disk electrode (GDE). In the entire studied $\mathrm{pH}$ (3.68-6.23), metal ions show two cathodic and an anodic peak. The method has also been employed to observe the interaction of metal ions with melamine in acetate buffer solution. At all $\mathrm{pH}$, a reasonably strong interaction occurs between metal ions and melamine at different metal ions/melamine molar ratio. However, maximum interaction takes place at 1:4 molar ratios of metal ions and melamine at $\mathrm{pH}$ 6.23. This is possibly the most suitable condition for alkaline earth metal-melamine interaction.
\end{abstract}

Key words: Melamine, acetate buffer, gold disk electrode, cyclic voltammetry, interaction

\section{Introduction}

Melamine (2,4,6-triamino-1,3,5-triazine, Mel) is a highly symmetrical ligand with six potential Ndonor atoms to coordinate to transition metals (Nockemann and Meyer 2004). The ligand, Mel, has both hydrogen bonding accepter and donor atoms which is analogous to nucleobases. Mel plays a role in a wide range of flame resistant materials as thermal liners, heat resistant gloves, and aprons to protect from splash back of hot substances. Mel derivatives of arsenical drugs are potentially important in the treatment of African trypanosomiasis (Lim et al. 1990). Standard tests such as the Kjeldahl and Dumas tests estimate protein levels by measuring the nitrogen content, so they can be misled by adding nitrogen-rich compounds such as Mel (Barrett and Gilbert 2006). As a fertilizer, Mel also showed economic benefit in agriculture.

The alkaline earth metals are a series of elements comprising Group 2 of the periodic table: beryllium $(\mathrm{Be})$, magnesium $(\mathrm{Mg})$, calcium $(\mathrm{Ca})$, strontium $(\mathrm{Sr})$, barium $(\mathrm{Ba})$ and radium $(\mathrm{Ra})$ (Royal Society of Chemistry 2012).

These highly reactive metals are present in nature and show common traits. Some of these elements are essential to life, and some are toxic, but all of them have important uses in modern manufacturing processes (Cox, 1989). Magnesium and calcium are critical to life. They play a vital role in the ion pumps that regulate cell behavior, and magnesium is the central atom in the chlorophyll molecule. Strontium has an important role in marine aquatic life, especially hard

*Corresponding author, Email: aftabshaikh@univdhaka.edu 
corals, which use strontium to build their exoskeletons. Other elements, including radium and beryllium, have no biological value and as such are toxic (Jakubke et al. 1994) to most organisms, including human.

Cyclic voltammetric method has been chosen for this present study because of its potential ability in investigating the redox behavior of electroactive species. The cyclic voltammetric study of various metal ions in presence of ligand has been investigated in our laboratory and reported in detail (Shaikh et al. 2005, 2006). We have therefore, started a wide ranging electrochemical studies of metal complexes of Mel using cyclic voltammetry. Here we report a study of cyclic voltammetric redox behavior of alkaline earth metal ions and their interaction with Mel in acetate buffer solution at different $\mathrm{pH}$.

\section{Materials and Methods}

Analar grade $\mathrm{MgCl}_{2} \cdot 6 \mathrm{H}_{2} \mathrm{O}, \mathrm{CaCl}_{2} \cdot 6 \mathrm{H}_{2} \mathrm{O}, \mathrm{SrCl}_{2} \cdot 6 \mathrm{H}_{2} \mathrm{O}$ and $\mathrm{BaCl}_{2} \cdot 2 \mathrm{H}_{2} \mathrm{O}$ have been purchased from Merck Germany and used without further purification. Analytical grade Mel (BDH, UK) was used in this study. Potassium chloride was purchased from BDH, England. For the preparation of acetate buffer solution, extra pure acetic acid (BDH, England) and sodium acetate (Merck, Germany) were procured and used without further treatment. Sodium hydroxide (Merck, Germany) was used as it is available for maintaining the $\mathrm{pH}$ of the solution. All aqueous solutions were prepared in doubly distilled water obtained from a Milli-Q water purification system. The experiments were carried out at room temperature.

Equipments: A three electrode electrochemical system consists of gold disk electrode (GDE) as the working electrode, $\mathrm{Ag} / \mathrm{AgCl}$ (satd. $\mathrm{KCl}$ ) as the reference electrode and platinum wire as the counter electrode was used. Cyclic voltammetric measurement was performed using Computerized Electrochemical System, Model HQ-2040 developed by Advanced Analytics, USA. Solution $\mathrm{pH}$ was measured by $\mathrm{pH}$ meter- Hanna instruments (model pH 211).

Preparation of acetate buffer solution: For the preparation of acetate buffer solution, $0.01 \mathrm{M}$ $\mathrm{CH}_{3} \mathrm{COONa} .3 \mathrm{H}_{2} \mathrm{O}$ and $0.01 \mathrm{M} \mathrm{CH}_{3} \mathrm{COOH}$ was prepared separately and the two solutions were then mixed together with same volume ratio. By adding $1.0 \mathrm{M} \mathrm{CH}_{3} \mathrm{COOH}$ and $1.0 \mathrm{M} \mathrm{NaOH}$, the desired $\mathrm{pH}(6.23,4.72,4.10$ and 3.68) values were adjusted.

Preparation of metal ion and melamine solution: Metal ion solution of $0.1 \mathrm{mM} \mathrm{Mg(II),}$ $\mathrm{Ca}(\mathrm{II}), \mathrm{Sr}(\mathrm{II})$ and $\mathrm{Ba}(\mathrm{II})$ were prepared in $0.1 \mathrm{M} \mathrm{KCl}$ and acetate buffer. For the complexation study, $0.2 \mathrm{mM}, 0.4 \mathrm{mM}, 0.6 \mathrm{mM}$ and $0.8 \mathrm{mM}$ Mel solution were also prepared in $0.1 \mathrm{M} \mathrm{KCl}$ and acetate buffer solution.

Preparation of working electrode: GDE was polished with fine alumina powder of 0.3 micron on a wet polishing cloth. For doing so a part of the cloth was made wet with deionized water and alumina powder was sprinkled over it. The GDE was then polished on this surface by pressing softly the electrode against the polishing surface for about 40-50 minutes. A shiny golden mirror like electrode surface was then thoroughly washed with deionized water. First of all, the cell was 
filled with desired volume of the experimental solution and the Teflon cap was placed on the cell. The purging glass tube together with reference electrode was inserted through the holes. Under computer controlled stirring, experimental solution was deaerated by purging for at least 10 minutes with $99.99 \%$ pure nitrogen gas. Thus traces of dissolved oxygen were removed from the solution.

\section{Results and Discussion}

Cyclic voltammetric investigation of the redox behavior of alkaline earth metal ions ( $\mathrm{Mg}(\mathrm{II})$, $\mathrm{Ca}(\mathrm{II}), \mathrm{Sr}(\mathrm{II})$ and $\mathrm{Ba}(\mathrm{II}))$ in $\mathrm{KCl}$ and acetate buffer solution and their interaction with Mel at GDE in an identical voltammetric condition has been performed. The effect of $\mathrm{pH}(6.23,4.72,4.10$, and 3.68) in $\mathrm{KCl}$ and acetate buffer was also examined in this study. The results are presented below:

Voltammetric response of metal ions in acetate buffer solution: Cyclic voltammetric response of $0.1 \mathrm{mM} \mathrm{Mg}(\mathrm{II}), \mathrm{Ca}(\mathrm{II}), \mathrm{Sr}(\mathrm{II})$ and $\mathrm{Ba}(\mathrm{II})$ in $0.01 \mathrm{M} \mathrm{KCl}$ and acetate buffer solution at different $\mathrm{pH}$ values $(\mathrm{pH} 6.23,4.72,4.10$ and 3.68) has been investigated at GDE within the potential window of -300 to $+1500 \mathrm{mV}$. For all metal ions, two cathodic and an anodic peak was observed.

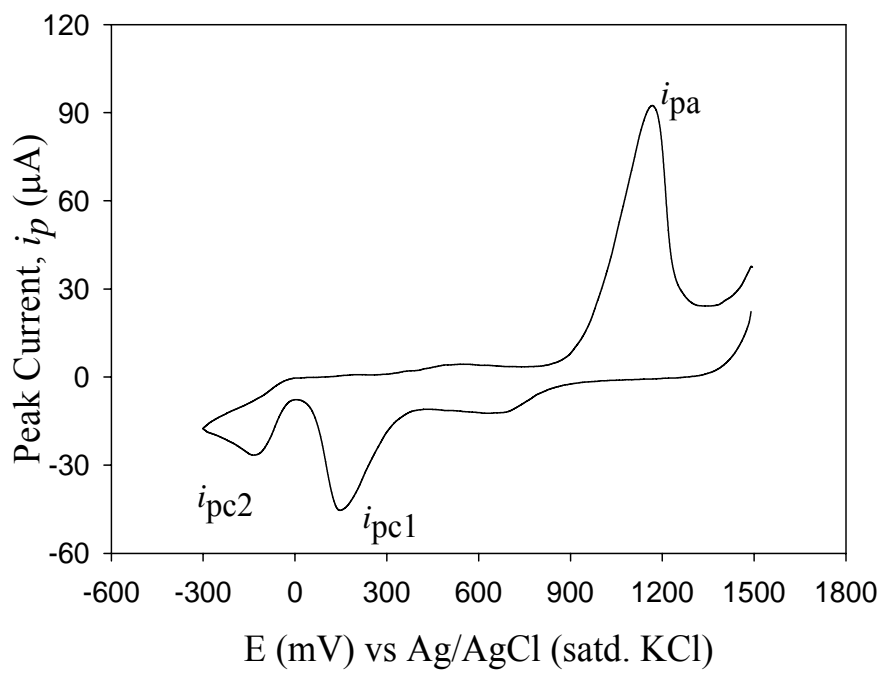

Fig. 1. Cyclic voltammogram of $0.1 \mathrm{mM} \mathrm{Sr}(\mathrm{II})$ in $0.01 \mathrm{M} \mathrm{KCl}$ at GDE with scan rate of $50 \mathrm{mVs}^{-1}$ at $\mathrm{pH} 6.23$.

At more positive or negative potential values only solvent decomposition current was found. Fig. 1 shows a cyclic voltammogram of $0.1 \mathrm{mM} \mathrm{Sr}(\mathrm{II})$ in $0.01 \mathrm{M} \mathrm{KCl}$ solution with scan rate of 50 $\mathrm{mVs}^{-1}$ at $\mathrm{pH}$ 6.23. In the forward scan two cathodic peak $i_{p c 1}$ and $i_{p c 2}$ at about $+145.6 \mathrm{mV}$ and $133.2 \mathrm{mV}$ respectively and in the reverse scan an intense anodic peak $i_{p a}$ at about $+1166.4 \mathrm{mV}$ was found. In the consecutive redox couple of $\operatorname{Sr}(\mathrm{II}) / \operatorname{Sr}(0)$, the cathodic peaks result from the reduction of $\operatorname{Sr}(\mathrm{II})$ to $\operatorname{Sr}(\mathrm{I})$ and $\operatorname{Sr}(\mathrm{I})$ to $\operatorname{Sr}(0)$, and the anodic peak is for the oxidation of $\operatorname{Sr}(0)$ to $\operatorname{Sr}(\mathrm{II})$. 
The above result suggests that at $\mathrm{pH} 6.23, \mathrm{Sr}(\mathrm{II})$ undergoes two electron transfer redox reaction. It agrees well with the previous study (Shaikh et al. 2011). The possible mechanism of the redox reaction is as follows:

For reduction reaction:

$$
\begin{aligned}
& \mathrm{Sr}(\mathrm{II})+\mathrm{e}^{-} \rightarrow \operatorname{Sr}(\mathrm{I}) \\
& \mathrm{Sr}(\mathrm{I})+\mathrm{e}^{-} \rightarrow \operatorname{Sr}(0)
\end{aligned}
$$

For oxidation:

$$
\operatorname{Sr}(0) \rightarrow \operatorname{Sr}(\mathrm{II})+2 \mathrm{e}^{-}
$$

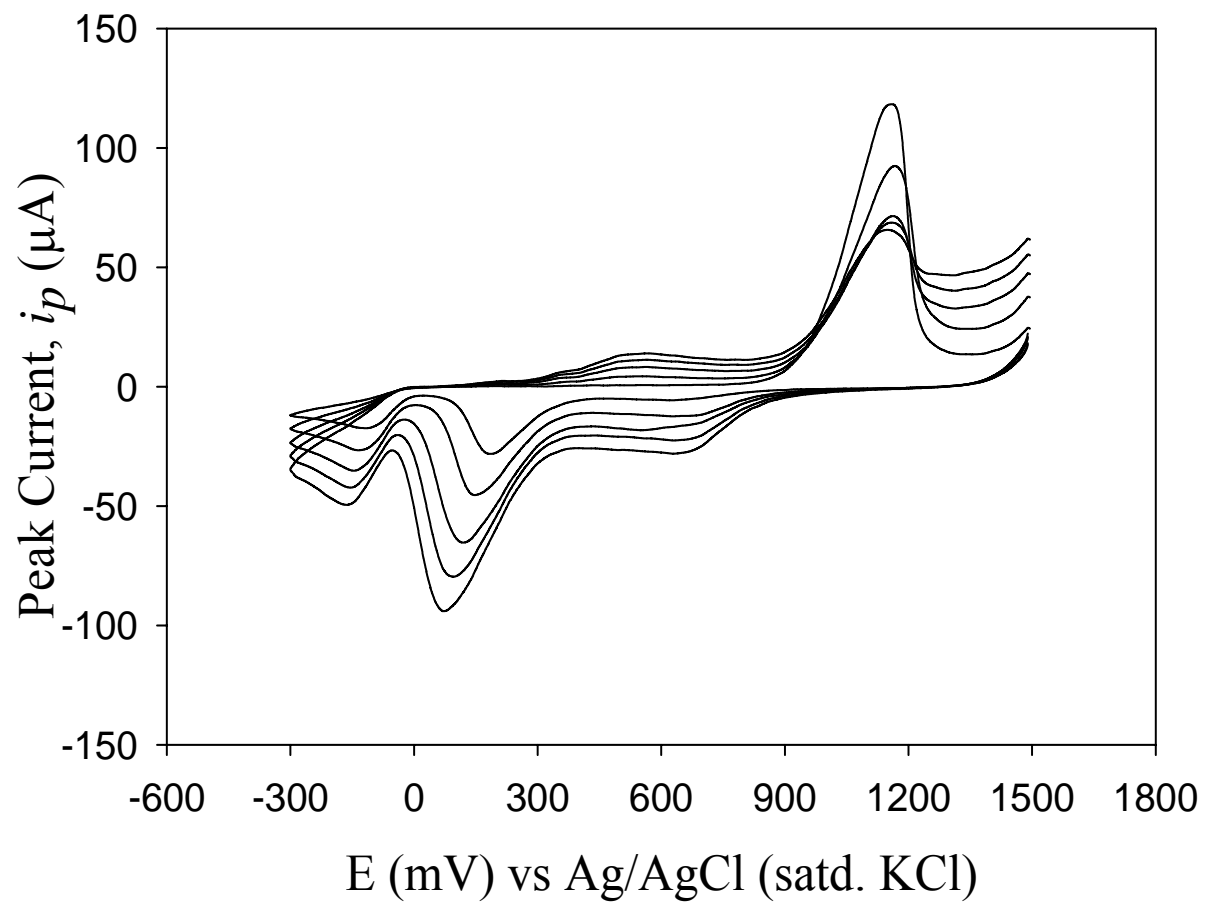

Fig. 2. Cyclic voltammograms of Sr(II) with different scan rate of $25,50,75,100$ and $125 \mathrm{mVs}^{-1}$ at $\mathrm{pH} 6.23$ at GDE.

Effect of scan rate: The effect of the scan rate on the electrochemical response of $\mathrm{Mg}(\mathrm{II})$, $\mathrm{Ca}(\mathrm{II}), \mathrm{Sr}(\mathrm{II})$ and $\mathrm{Ba}(\mathrm{II})$ at $\mathrm{pH} 6.23$ is also examined by recording their cyclic voltammograms with scan rate of $25,50,75,100$ and $125 \mathrm{mVs}^{-1}$. The cyclic voltammograms of $\mathrm{Sr}$ (II) with scan rate of $25,50,75,100$ and $125 \mathrm{mVs}^{-1}$ were recorded under identical condition ( $0.1 \mathrm{mM} \mathrm{Sr}$ (II) in $0.01 \mathrm{M} \mathrm{KCl})$. The voltammograms obtained are shown in Fig. 2.

The recorded voltammograms are analyzed and various parameters such as anodic and cathodic peak current, peak potential separation and peak current ratio are recorded. It is found that with the increase of scan rate, both the cathodic and andodic peak current is increased (Fig. 2). 
The peak potential separation and peak current ratio reveal that the redox process of $\operatorname{Sr}(\mathrm{II}) / \operatorname{Sr}(0)$ is quasi-reversible which is also characterized by the shape of the cathodic and anodic peaks (Quentel and Madec 1990). The peak potential separation (972.8-1079.2 mV) and peak current ratio (0.37- 4.20) also reveals that the redox process of $\operatorname{Sr}(\mathrm{II}) / \operatorname{Sr}(0)$ is quasi-reversible. It is observed that the cathodic peak is slightly shifted towards negative potential while the anodic peak is moved a little towards positive potential with the incease of scan rate. The shifting of the peak potential at various scan rates also indicates that the redox process is shifted from quasi-reversible to irreversible direction.

Fig. 3 apparently shows that the peak current for the redox system of $\operatorname{Sr}(\mathrm{II}) / \operatorname{Sr}(0)$ has a linear relationship with square root of scan rate and it passes through the origin. This observation is in favor of the fact that the electrode process is diffusion controlled rather than adsorption on the electrode surface. It is also in good agreement with the previous study (Akhtar et al. 2008).

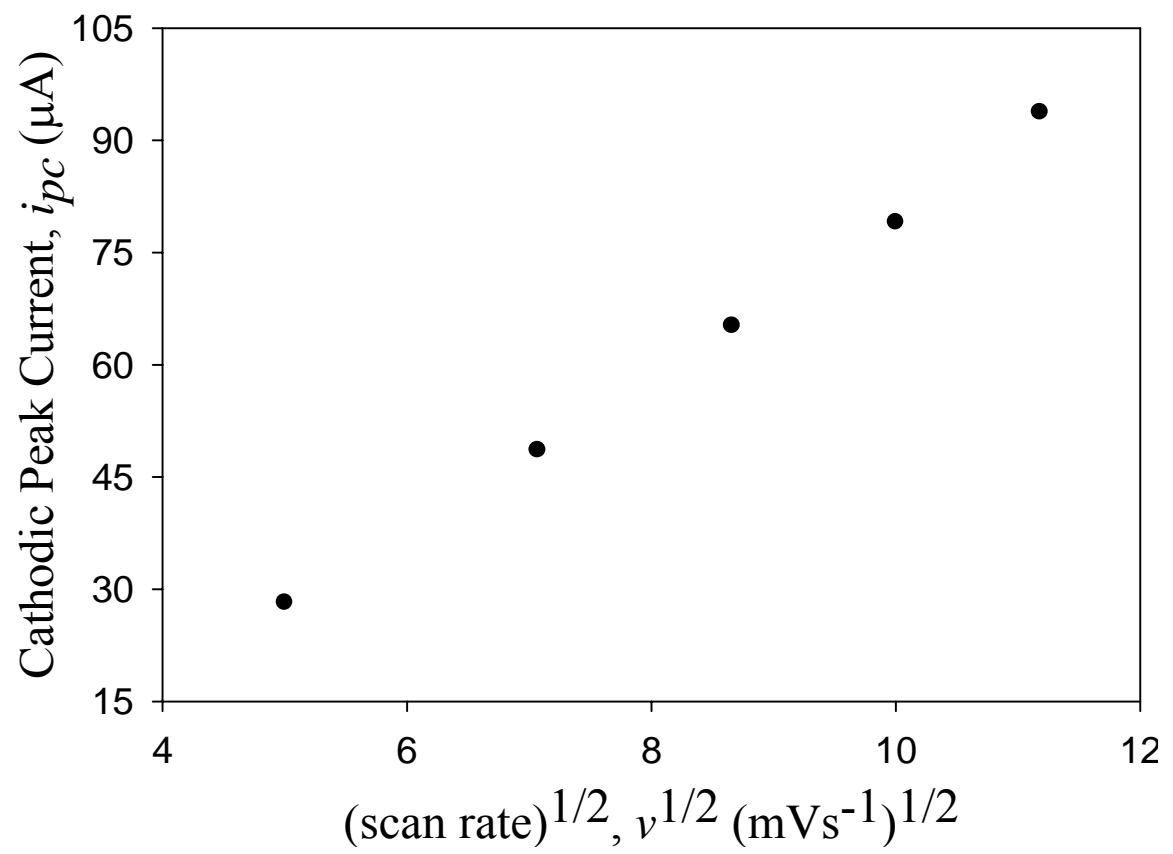

Fig. 3. Dependence of peak current with square root of scan rate for strontium system in $0.01 \mathrm{M} \mathrm{KCl}$ at $\mathrm{pH}$ 6.23 .

The peak potential separation, $\Delta \mathrm{E}_{\mathrm{p}}$ is in between $972.8-1079.2 \mathrm{mV}$ and it is increased with the increase of scan rate (Fig. 4). These observations suggest that the redox process is quasi-reversible reaction rather than a reversible process. 
Effect of $\mathrm{pH}$ on the redox reaction of metal ions: The effect of $\mathrm{pH}$ on the electrochemical redox reaction of $\mathrm{Mg}(\mathrm{II}), \mathrm{Ca}(\mathrm{II}), \mathrm{Sr}(\mathrm{II})$ and $\mathrm{Ba}(\mathrm{II})$ at $\mathrm{pH}(6.23,4.72,4.10$ and 3.68) has been investigated with GDE. A series of recorded voltammograms at different $\mathrm{pH}$ for $\mathrm{Sr}(\mathrm{II})$ are shown in Fig. 5. At lower $\mathrm{pH}$ (using acetate buffer) ranging from 3.68 to 4.72 , one cathodic and an intense anodic peak were appeared. With the decrease of $\mathrm{pH}$ the anodic peak became sharper and

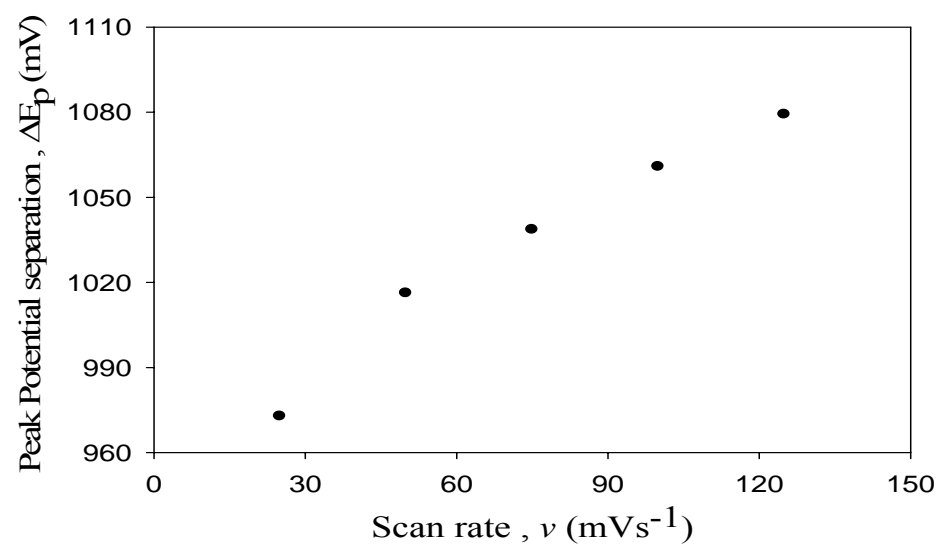

Fig. 4. Variation of peak potential separation with scan rate for $0.1 \mathrm{mM} \mathrm{Sr}(\mathrm{II})$ in $0.01 \mathrm{M} \mathrm{KCl}$ solution at $\mathrm{pH}$ 6.23 .

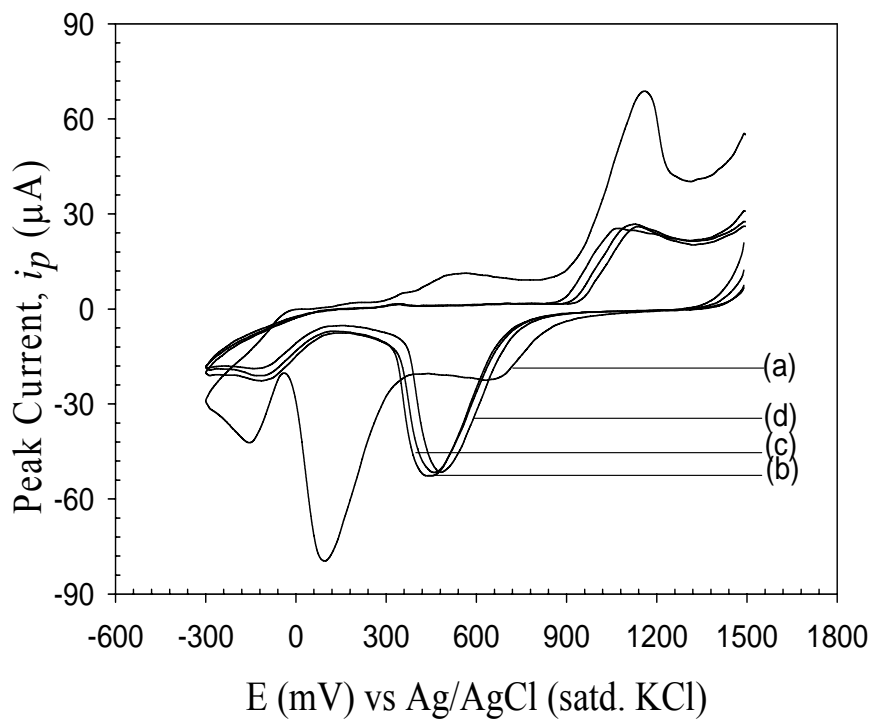

Fig. 5. Cyclic voltammograms of $\mathrm{Sr}(\mathrm{II})$ at (a) $\mathrm{pH}$ 6.23, (b) $\mathrm{pH} 4.72$, (c) $\mathrm{pH} 4.10$ and (d) $\mathrm{pH} 3.68$ with scan rate of $100 \mathrm{mVs}^{-1}$.

cathodic peak shifted to more positive potential as given in Table 1. Although at lower $\mathrm{pH}$ one cathodic and one anodic peak were found, at higher $\mathrm{pH}(\mathrm{pH} 6.23$, solution prepared with $0.01 \mathrm{M}$ $\mathrm{KCl})$ two cathodic and one anodic peak were observed. At lower $\mathrm{pH}$ the disappearance of one of 
the cathodic peaks is probably due to the presence of acetate buffer solution. In the case of $\mathrm{pH}$ 6.23 , only $\mathrm{KCl}$ solution was used as a supporting electrolyte solution while in the other $\mathrm{pH}$, acetate buffer was used as a supporting electrolyte.

Table 1. The data obtained for the voltammograms of Sr(II) system at different pH.

\begin{tabular}{|c|c|c|c|c|c|c|c|c|c|c|}
\hline \multirow[t]{2}{*}{$\begin{array}{l}\text { Solution } \\
\mathrm{pH}\end{array}$} & \multicolumn{2}{|l|}{$\begin{array}{l}\text { Anodic } \\
\text { peak } \\
\text { current }\end{array}$} & \multicolumn{2}{|c|}{$\begin{array}{l}\text { Cathodic peak } \\
\text { current }(\mu \mathrm{A})\end{array}$} & \multicolumn{2}{|c|}{$\begin{array}{l}\text { Anodic peak } \\
\text { potential }(\mathrm{mV})\end{array}$} & \multicolumn{2}{|c|}{$\begin{array}{l}\text { Cathodic peak } \\
\text { potential }(\mathrm{mV})\end{array}$} & \multicolumn{2}{|c|}{$\Delta \mathrm{E}=\mathrm{E}_{\mathrm{pa}}-\mathrm{E}_{\mathrm{pc}}$} \\
\hline & $i_{p a 1}$ & $i_{p a 2}$ & $i_{p c 1}(-)$ & $i_{p c 2}(-)$ & $\mathrm{E}_{\mathrm{pa} 1}$ & $\mathrm{E}_{\mathrm{pa} 2}$ & $\mathrm{E}_{\mathrm{pc} 1}$ & $\mathrm{E}_{\mathrm{pc} 2}(-)$ & $\Delta \mathrm{E}_{1}$ & $\Delta \mathrm{E}_{2}$ \\
\hline 6.23 & 68.99 & - & 79.63 & 42.14 & 1160.4 & - & 94 & 156 & 1066.4 & - \\
\hline 4.72 & 25.58 & - & 51.24 & - & 1064.8 & - & 456.4 & - & 607.6 & - \\
\hline 4.10 & 25.84 & - & 53.14 & - & 1116.8 & - & 442 & - & 674.8 & - \\
\hline 3.68 & 26.15 & - & 51.81 & - & 1137.6 & - & 483 & - & 654.6 & - \\
\hline
\end{tabular}

Dash (-) indicate no significant values

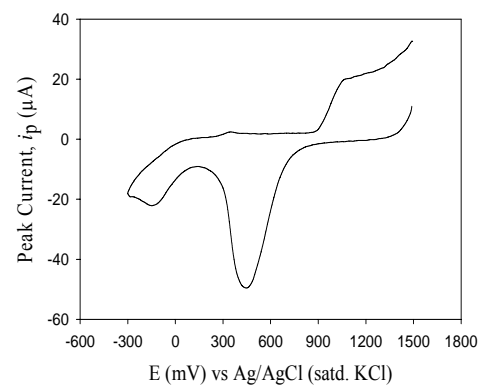

(i)

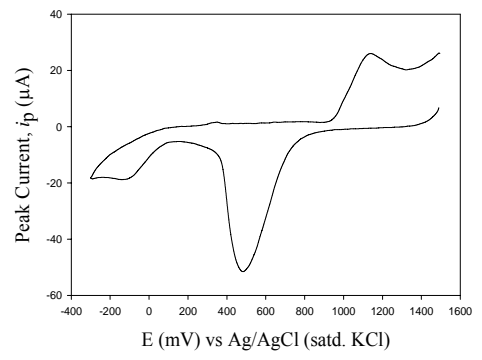

(iii)

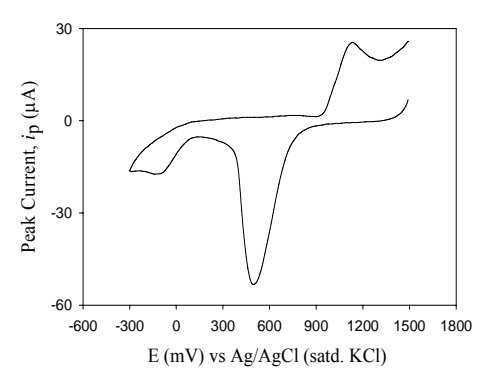

(ii)

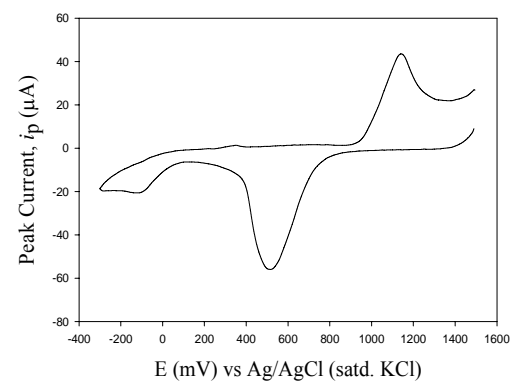

(iv)

Fig. 6. Cyclic voltammograms of $1.0 \mathrm{mM}$ (i) $\mathrm{Mg}$ (II), (ii) $\mathrm{Ca}$ (II), (iii) $\mathrm{Sr}$ (II), (iv) $\mathrm{Ba}$ (II) at $\mathrm{pH} 4.72$ with scan rate of $100 \mathrm{mVs}^{-1}$ at GDE.

Comparative studies of the voltammetric behavior of different members of alkaline earth metal ions, cyclic voltammograms were recorded for all metal ions at $\mathrm{pH} 4.72$ and they are shown in Fig. 6. From the figures it is found that at studied $\mathrm{pH}$ all the metal ions show the identical behavior. 
Voltammetric response of metal ions in presence of melamine in acetate buffer solution: The voltammograms of $\mathrm{Mg}(\mathrm{II}), \mathrm{Ca}(\mathrm{II}), \mathrm{Sr}(\mathrm{II})$ and $\mathrm{Ba}(\mathrm{II})$ in presence of $\mathrm{Mel}$ at various metal/Mel molar ratio $(1: 1,1: 2,1: 3$ and $1: 4)$ at different $\mathrm{pH}(6.23,4.72,4.10$ and 3.68) in acetate buffer (except $\mathrm{pH}$ 6.23 ) have been recorded at GDE within the identical potential window. Fig. 7 shows the recorded voltammograms of $\mathrm{Sr}(\mathrm{II})$, and $\mathrm{Sr}(\mathrm{II})$ in presence of Mel with different molar concentration at $\mathrm{pH}$ 6.23. A dramatic change of the shape of voltammograms is observed. The anodic peak is completely disappeared especially at higher molar concentration of Mel, and both cathodic and anodic peak current drastically decreased than that of solely $\mathrm{Sr}$ (II) for each molar ratio of $\mathrm{Sr}$ (II) and Mel.

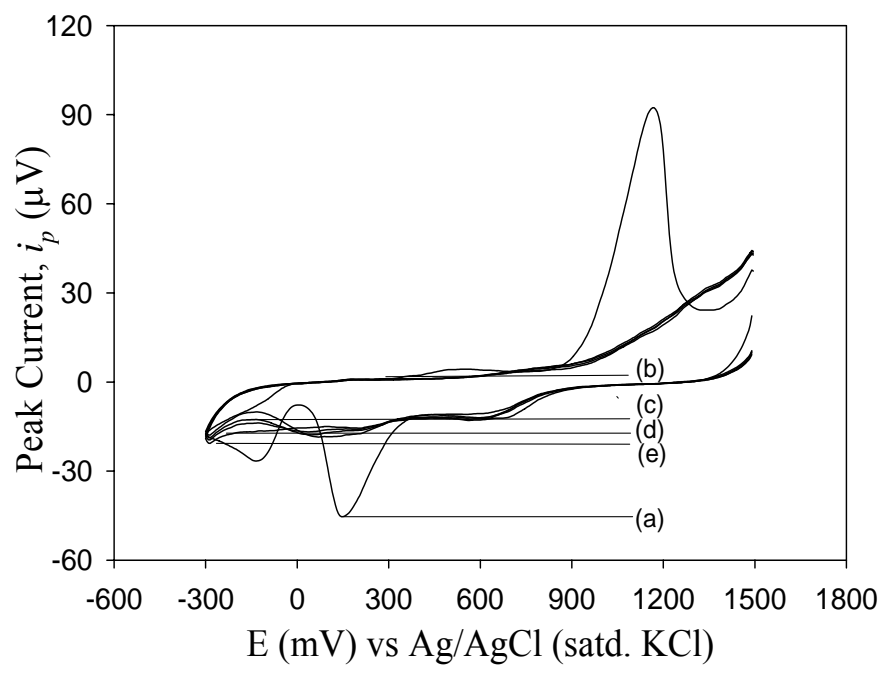

Fig. 7. Cyclic voltammograms of $0.1 \mathrm{mM}$ (a) Sr(II), (b) 1:1, (c) 1:2, (d) 1:3 and (e) 1:4 ratio of $\mathrm{Sr}$ (II) and Mel at GDE with scan rate of $50 \mathrm{mVs}^{-1}$ at $\mathrm{pH} 6.23$.

In presence of $\mathrm{Mel}$ the cathodic peak potentials also shifted slightly towards negative direction. Furthermore, the heights of the peaks are apparently inconsistent with respect to Mel concentration. Since the lowest peak current (Table 2) is found for 1:4 molar ratio of $\operatorname{Sr}($ II) and $\mathrm{Mel}$, the maximum interaction is indeed, occurred with this molar ratio at this $\mathrm{pH}$ medium. It is noted that the voltammogram of Mel in identical condition exhibits no anodic or cathodic peak within the studied potential window.

Again, the voltammograms of $\mathrm{Sr}(\mathrm{II})$ at various $\mathrm{Sr}(\mathrm{II}) / \mathrm{Mel}$ molar ratio (1:1, 1:2, 1:3 and 1:4) at $\mathrm{pH} 4.72$ (in acetate buffer) have also been examined. At this $\mathrm{pH}$, the anodic peak is almost disappeared but more intense cathodic peak is obtained. The peak currents are relatively lower and the peak potentials are also shifted than that of $\mathrm{Sr}$ (II) alone (Fig. 8). The lowest peak current is again found at 1:4 molar ratio of $\mathrm{Sr}(\mathrm{II})$ and $\mathrm{Mel}$ and thus the maximum interaction occurs at this composition. 


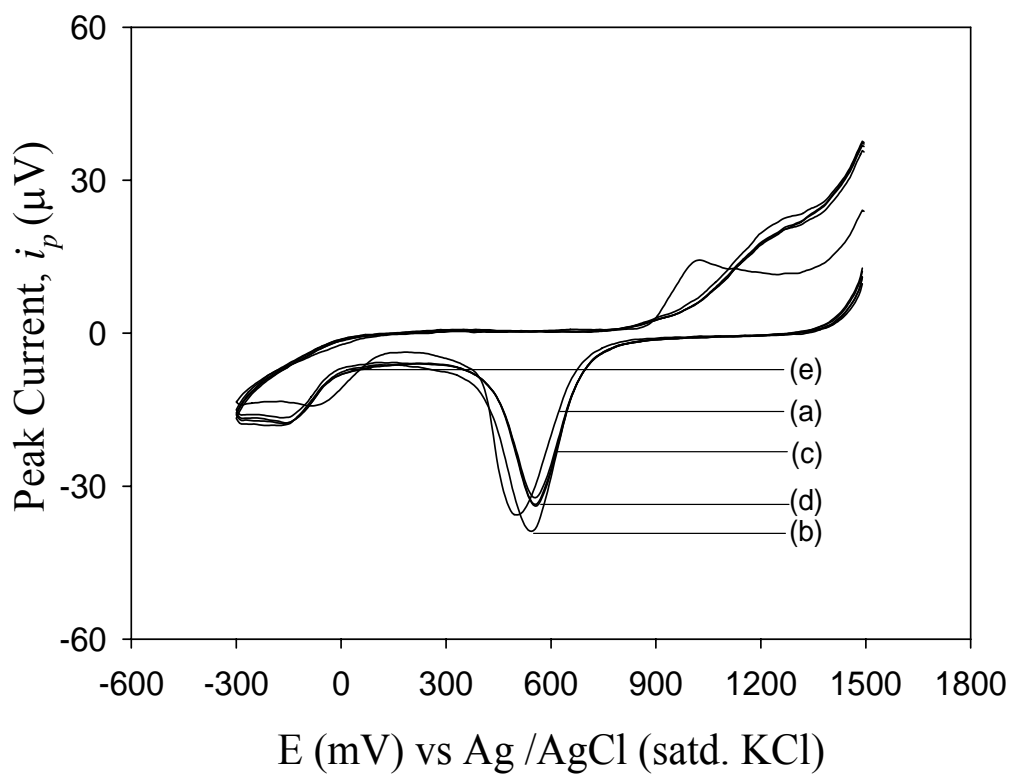

Fig. 8. Cyclic voltammograms of $0.1 \mathrm{mM}$ (a) $\mathrm{Sr}(\mathrm{II})$, and $\mathrm{Sr}(\mathrm{II})$ and Mel with different ratio (b) 1:1, (c) 1:2, (d) $1: 3$ and (e) $1: 4$ at $\mathrm{pH} 4.72$ with scan rate of $50 \mathrm{mVs}^{-1}$.

In presence of Mel, $\mathrm{Sr}$ (II) displays almost identical electrochemical behavior at $\mathrm{pH} 4.10$ and at 3.69. The voltammograms recorded at $\mathrm{pH} 4.10$ and at 3.69 are shown in Figs. 9 and 10 respectively. It is needed to be mentioned here that at these $\mathrm{pH}$ the cathodic peak has shifted slight more positive direction than those of other $\mathrm{pH}$.

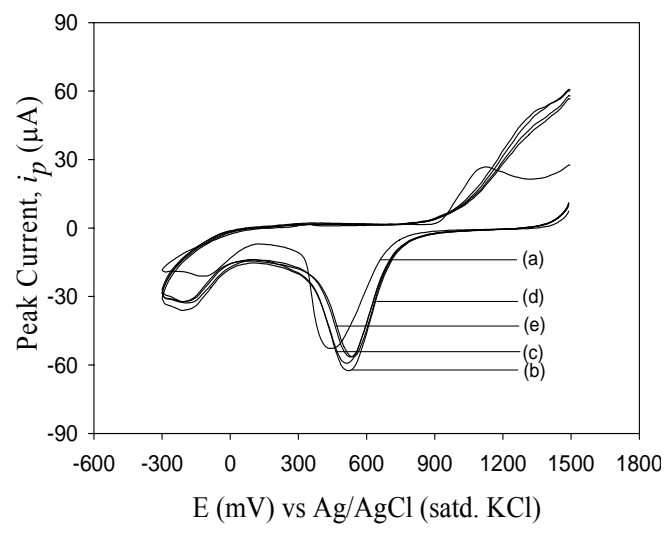

Fig. 9. Cyclic voltammograms of $0.1 \mathrm{mM}$ (a) $\mathrm{Sr}(\mathrm{II}), \mathrm{Sr}(\mathrm{II})$ and Mel with different ratio (b) 1:1, (c) 1:2, (d) 1:3 and (e) $1: 4$ at $\mathrm{pH} 4.10$ with scan rate $100 \mathrm{mVs}^{-1}$.

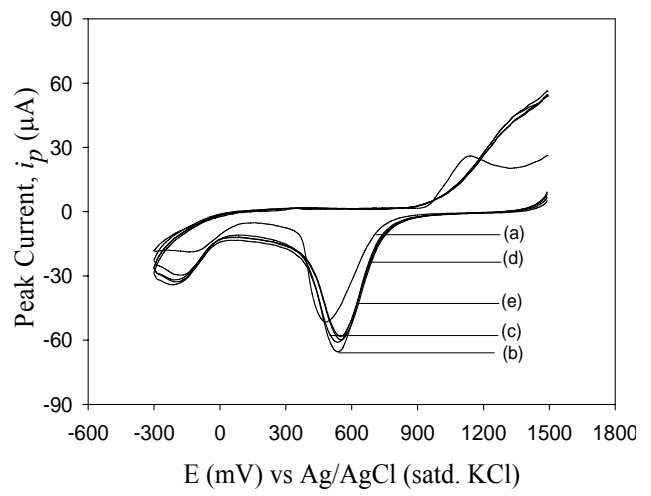

Fig. 10. Cyclic voltammograms of $0.1 \mathrm{mM}$ (a) $\mathrm{Sr}(\mathrm{II})$, $\mathrm{Sr}(\mathrm{II})$ and Mel with different ratio (b) $1: 1$, (c) $1: 2$, (d) $1: 3$ and (e) $1: 4$ at $\mathrm{pH} 3.68$ with scan rate $100 \mathrm{mVs}^{-1}$. 
The data for the different voltammograms recorded for $\mathrm{Sr}$ (II)/Mel molar ratio of 1:4 at various $\mathrm{pH}$ is gathered in Table 2 .

Table 2. The data for the voltammograms recorded for 1:4 molar ratio of $\mathrm{Sr}(\mathrm{II}) / \mathrm{Mel}$ at different $\mathrm{pH}$ with scan rate of $100 \mathrm{mVs}^{-1}$.

\begin{tabular}{lcccccc}
\hline $\begin{array}{l}\text { Solution } \\
\mathrm{pH}\end{array}$ & \multicolumn{2}{c}{ Peak current, $\mu \mathrm{A}$} & \multicolumn{2}{c}{ Peak potential, $\mathrm{mV}$} & $\begin{array}{c}\text { Peak current ratio } \\
\left(i_{p a} / i_{p c}\right)\end{array}$ & $\begin{array}{c}\text { Peak potential } \\
\text { separation, } \Delta \mathrm{E}_{\mathrm{p}}\end{array}$ \\
\cline { 2 - 7 } & $i_{p c}(-)$ & $i_{p a}$ & $\mathrm{E}_{\mathrm{pc}}(-)$ & $\mathrm{E}_{\mathrm{pa}}$ & & \\
\hline 6.23 & - & - & - & - & - & - \\
4.72 & 32.22 & - & 553.6 & - & - & - \\
4.10 & 56.18 & - & 529.2 & - & - & - \\
3.68 & 56.10 & - & 550.4 & - & - & - \\
\hline
\end{tabular}

Dash (-) indicate no significant values

Like $\mathrm{Sr}(\mathrm{II})$, other alkaline earth metals ( $\mathrm{Mg}(\mathrm{II}), \mathrm{Ca}(\mathrm{II})$ and $\mathrm{Ba}(\mathrm{II})$ ) show identical behavior in acetate buffer solution at different $\mathrm{pH}$, and their interaction with Mel at GDE. Fig. 11 shows the recorded voltammograms of $\mathrm{Ca}(\mathrm{II})$, and $\mathrm{Ca}(\mathrm{II})$ in presence of Mel with different molar concentration at $\mathrm{pH} 4.10$.

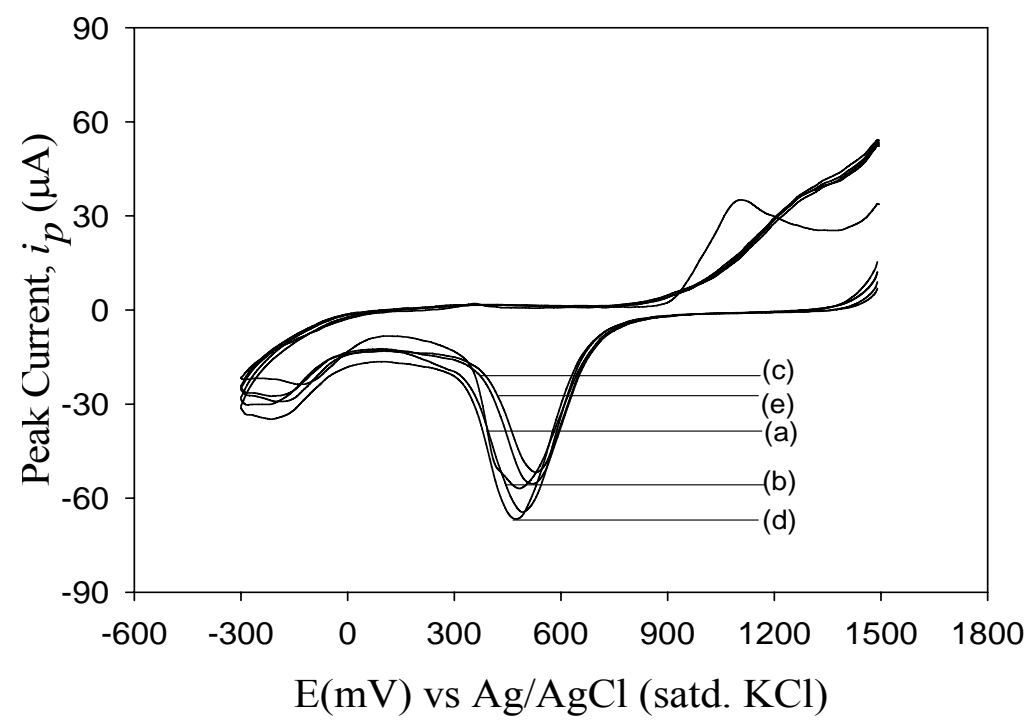

Fig. 11. Cyclic voltammograms of $0.1 \mathrm{mM}$ (a) $\mathrm{Ca}(\mathrm{II})$, and $\mathrm{Ca}$ (II) and Mel with different molar ratio (b)1:1, (c) $1: 2$, (d) $1: 3$ and (e) $1: 4$ in acetate buffer at $\mathrm{pH} 4.10$ with scan rate $100 \mathrm{mVs}^{-1}$.

\section{Conclusion}

The electrochemical redox behavior of alkaline earth metal ions ( $\mathrm{Mg}(\mathrm{II}), \mathrm{Ca}(\mathrm{II}), \mathrm{Sr}(\mathrm{II})$ and $\mathrm{Ba}(\mathrm{II})$ ) in $0.01 \mathrm{M} \mathrm{KCl}$ and acetate buffer has been studied at different $\mathrm{pH}(6.23,4.72,4.10$ and 3.68). At 
pH 6.23 (in $0.01 \mathrm{M} \mathrm{KCl),} \mathrm{the} \mathrm{voltammograms} \mathrm{of} \mathrm{the} \mathrm{studied} \mathrm{systems} \mathrm{show} \mathrm{two} \mathrm{cathodic} \mathrm{and} \mathrm{an}$ anodic peak. While at $\mathrm{pH}(4.72,4.10$ and 3.68) in acetate buffer medium one anodic and one cathodic peak is observed. The peak potential separation, and peak current ratio of the systems $\mathrm{Mg}(\mathrm{II}) / \mathrm{Mg}(0), \mathrm{Ca}(\mathrm{II}) / \mathrm{Ca}(0), \mathrm{Sr}(\mathrm{II}) / \mathrm{Sr}(0)$ and $\mathrm{Ba}(\mathrm{II}) / \mathrm{Ba}(0)$ reveal that the redox processes are quasi-reversible. The linear behavior of peak current vs. square root of scan rate plot suggests that electrode processes are diffusion controlled. In presence of Mel, in acetate buffer medium at $\mathrm{pH}$ (4.72, 4.10 and 3.68), the anodic peak is completely disappeared while cathodic peak intensity slightly increases. Moreover, cathodic peaks are shifted towards positive direction. Nevertheless, at $\mathrm{pH} 6.23$, both of the cathodic and the anodic peak are almost disappeared. This observation indicates that the strong interaction occurs between metal ions and $\mathrm{Mel}$ at $\mathrm{pH} 6.23$ in $0.01 \mathrm{M} \mathrm{KCl}$ at a molar ratio of 1:4.

\section{Acknowledgement}

The authors are grateful to the University of Dhaka for financial support to carry out the research work.

\section{References}

Akhtar, H. M. N., M. M. Jamal, A. A. Shaikh and M. Q. Ehsan. 2008. Cyclic voltammetric study of the interaction of copper with glutamic acid in solution. J. Saudi Chem. Soc., 12(2):177-182.

Barrett, M.P. and I.H. Gilbert. 2006. Targeting of toxic compounds to the trypanosome's interior. Adv. Parasitol. 63:125-83.

Jakubke, Hans-Dieter, Hans Jeschkeit. eds. 1994. Concise Encyclopedia Chemistry. Trans. Rev. Mary Eagleson.-Berlin, New York, Walter de Gruyter.

Lim, L.O., S. J. Scherer and K.D. Shuler. 1990. Disposition of cyromazine in plants under environmental conditions. J. Agric. Food Chem. 38:860-64.

Nockemann, P. And G. Meyer. 2004. Zwitterionic Melaminium trichloro-mercurate(II), $\left[\mathrm{MelH}^{+} \mathrm{HgCl}_{3}^{-}\right.$ ](Mel). Z. Anorg. Allg. Chem. 630:2571-72.

Cox, P.A. 1989. in The Elements: Their Origin, Abundance, and Distribution, Oxford University Press, Oxford, UK.

Quentel, F. and C. Madec. 1990. Voltammetric study of the copper-1,10-phennthroline complex. Anal. Chem. Acta. 230:83-90.

Royal Society of Chemistry, "Visual Elements: Group 2- The Alkaline Earth Metals". Retrieved 13 January, 2012.

Shaikh, A.A., S.N. Afzal, M.Q. Ehsan and A.H. Khan. 2005. Electrochemical study on redox reaction of iodine and bromine in presence of benzoylacetone at carbon electrodes. J. Saudi Chem. Soc., 9(2):279286. 
Shaikh, A.A., M. Begum, A.H. Khan and M.Q. Ehsan. 2006. Cyclic voltammetric studies of the redox behavior of iron(III)-vitamin $\mathrm{B}_{6}$ complex at carbon paste electrode. Russ. J. Electrochem. 42(6):620625.

Shaikh, A.A., J. Firadows, Badrunnessa, S. Serajee, M.S. Rahman and P.K. Bakshi. 2011. Electrochemical studies of the $\mathrm{pH}$ dependence of $\mathrm{Cu}(\mathrm{II})$ reduction in aqueous britton-robinson buffer solution. Int. J. Electrochem. Sci. 6:2333-2343.

(Manuscript received on 15 April, 2013; revised on 22 June 2014) 